\title{
A Companion to German-Language Sociology
}

This book provides the first systematic overview of the current state of sociology in German-speaking countries in the English language. Its thirty-four chapters review advances and current trends, relate them to the international discussion and point out challenges and perspectives for future research. As the variety of topics shows, the contributions to this volume span the entire range of sociological research areas that address pressing questions both theoretically and empirically.

With this special issue of the SOZIOLOGISCHE REVUE, the only German-language sociological review journal, we want to give international readers some insight into the sociological discussions in German-speaking countries-that is, Germany, Austria, and parts of Switzerland-and familiarize them with the discussions that are still largely conducted in the German language. We believe that many aspects of these discussions are of interest to an international audience as well and that knowledge about the wider context of the history of ideas in which the German-language debate is embedded and how it has evolved over time will not only enhance mutual understanding but might also stimulate and fertilize the broader international debate.

In the following, we will first briefly address some characteristics of the Germanlanguage sociological discourse and its historical background. Second, we will address the question why, despite the increasing internationalization of Germanspeaking academia, a substantial part of the sociological discussion is still being conducted in the German language. Finally, we provide the reader with some guidance on what to expect in the articles to follow and offer some tips on how to navigate this volume.

\section{Is There a "German-Language Sociology"?}

When we approached the experts who contributed to this volume, we asked them to review the research literature and the discussion in German-language sociology in their fields of expertise over the last 15 to 20 years. Specifically, we asked them to identify the defining features of the discussion in these fields and relate them to the international debate. Are there specific topics or certain perspectives that are characteristic of the German-language academic discussion? What have been the particular advances during this period? Are there areas in which the discussion is perhaps lagging behind? Are there specific highlights or "selling points" unique to the discussion in German-language sociology and, if so, what specifically have they yielded in terms of our understanding of the respective topic?

Despite stark differences among the different sociological fields, we can identify some features that are widely shared among much of the German-speaking sociological community. 
Perhaps the most distinct feature of the debates among German-speaking sociologists is the generally strong interest in philosophically informed theory, methodology, and epistemology. The political scientist and sociologist Johan Galtung (1981) once spoke of a "teutonic" intellectual style in German-speaking countries, ${ }^{1}$ which he compared to the "saxonic" intellectual style in British and US academia. While Galtung saw the "saxonic" style as being characterized by a primarily empirical, strongly data-driven approach that is less theory oriented, he perceived the "teutonic" style as being marked by a stronger focus on theory-building and analysis of the underlying paradigms. Although this characterization may be a bit stereotypical, it underlines the fact that German-language sociology has strong roots in Geisteswissenschaften (humanities) and idealism.

As Alvin Gouldner pointed out, German social science "developed out of a dialectic between Romanticism and science” (Gouldner, 1973: 93). This tension between Geisteswissenschaften and science, between idiographic hermeneutic traditions and nomographic deductive science can be found in the works of the classics, such as Karl Marx, Georg Simmel, and Max Weber, and has been a leitmotif in German-language sociology ever since-with times of more or less "peaceful co-existence" and phases of fierce debates, such as the Popper-Adorno controversy (the so-called Positivismusstreit [positivism dispute]) in the early 1960s (Adorno, 1969).

Beyond these theoretical and intellectual roots that extend far back in time, the political and social upheavals of the 20th century left their imprint and continue to influence German-language sociology still today. During the Nazi regime, many sociologists fled Germany and Austria and frequently went into exile in the United States, where they became influential members of the sociological community, amalgamating German traditions with the US-American style of sociological work.

The year 1945 marked a historical break that motivated many students to study sociology who later went on to shape the development of the discipline (cf. Fleck, 1996; Bolte and Neidhardt, 1998). As Heinz Bude and Friedhelm Neidhardt describe in a volume that contains autobiographical memories of sociologists of this generation, born in the 1920s, these young people sought to understand this dramatic societal discontinuity, "where in some respects everything was different, but in other respects much remained the same. The politics, the economy, or the law had changed radically, but, if they had survived, the people in their families, in their neighborhoods, or in the conversations on the corner were basically the same as before" (Bude and Neidhardt, 1998: 407; our translation). This young generation of sociologists, such as Ralf Dahrendorf, Renate Mayntz, or Erwin K. Scheuch, was generally very skeptical of 'grand theory,' and was characterized above all by a strong orientation towards empirical research, in many cases promoted and intensified by research stays in the US (Bolte and Neidhardt, 1998).

1 According to Fiedler, the "teutonic" intellectual style can also be found in Eastern Europe and Russia (2012). 
The next generation, in the late 1960s, was inspired by a global student movement, which in West Germany was characterized by a deeply felt moral indignation about the ways that the German mainstream had dealt with its Nazi past. This generation connected with the work of exiled scholars-both those still in the US and those who had returned-and revived an interest in theory, especially in the works of Marx, the critical Frankfurt School, and Freudian psychoanalysis. Inspired by the 'new social movements,' the expansion of the higher-educational system, and a broad, enduring cultural change, the sociology of the 1960s also witnessed serious theoretical and methodological debates, such as the aforementioned Positivismusstreit. The so-called Theorienvergleichsdebatte (methodologically reflected comparison of different theoretical paradigms) in the 1970s tried to integrate the different sociological paradigms as complementary approaches to the social world (Hondrich and Matthes, 1978). In the 1980s, the discussion about Habermas' normatively imbued theory of communicative action and Luhmann's systems theory, which denied all moral implications, dominated the debate in social theory. ${ }^{2}$

In the GDR and Austria, by contrast, the student movement was not as pronounced and influential as it was in West Germany, although for different reasons. Austria had witnessed no such dramatic social discontinuity comparable to that in Germany after 1945. Officially, Austria never fully acknowledged its own National Socialist past, and the small student movement encountered much more ossified structures than in Germany (cf. Lepsius, 1989). In the GDR, the socialist regime that built the Berlin Wall in the early 1960s had officially overcome the fascist Nazi regime and any student movement was suppressed (Wolle, 2001).

After 1989, German reunification strongly affected the economic, social, and political development in Germany. Germany's demography changed owing to high unemployment rates and economic insecurity in East Germany, which induced a massive decrease in fertility in the East and motivated many among the better educated to seek their fortune in the western parts of the country. The various aspects of the intense societal change that emerged in the wake of reunification became the subject of a special area of sociological research that has been termed Transformationsforschung (Teckenberg, 2000) but were also thoroughly investigated in other fields of sociology (see, e.g., Höpflinger, DEMOGRAPHY AND AGING, this volume; Konietzka/Feldhaus/ Kreyenfeld/Trappe, FAMILY AND INTIMATE RELATIONSHIPS, this volume; Koenig, RELIGION, this volume). At first glance, it seemed as if this unification was predominantly a "Westernization" of the former GDR and that West Germany was less affected by the fall of the Berlin Wall. ${ }^{3}$ Yet this proved true only in the short run. Today, all of

2 On the various debates, see Kneer and Moebius (2010) and Moebius (HISTORY OF SOCIOLOGY, this volume).

3 This was also true for the development of East German sociology, which was shaped by MarxismLeninism and had evolved separately with almost no contact to West German sociology (cf. Meyer, 1994). After unification, the former social-science departments at GDR academic institutions were dis- 
Germany is affected by increasing inequality, internal East-West migration, recent political polarizations, the re-emergence of right-wing movements, and threats to social cohesion. In fact, this applies to all German-speaking countries and across all of Europe. All of these topics have increasingly become a subject of sociological research in recent years, in particular in political sociology (Lamla, POLITICAL SOCIOLOGY, this volume), the sociology of social movements (Kern, SOCIAL MOVEMENTS, this volume), of migration (Pries, MIGRATION, this volume), and of social inequality (Otte/ Boehle/Kunißen, SOCIAL INEQUALITIES-EMPIRICAL FOCUS, this volume).

\section{Internationalization and Institutionalization of German-Language Sociology}

As mentioned above, the degree of internationalization varies remarkably among different sociological fields. In some areas, discussions overwhelmingly take place in German-a situation similar to the largely Francophone debates in France-even though there are many interesting contributions that could enrich the international debate, for instance, in sociological theory (Schneider, SOCIAL THEORY, this volume; Schimank, SOCIETY, this volume; Schützeichel, MICROSOCIOLOGY, this volume), qualitative research methods (Hollstein/Kumkar, QUALITATIVE METHODS, this volume), cultural sociology (Karstein/Wohlrab-Sahr, CULTURE, this volume), biographical research (Huinink/Hollstein, LIFE COURSE, this volume), and the history of sociology (Moebius, HISTORY OF SOCIOLOGY, this volume). Other fields of research are highly internationalized with most research published in English, such as life-course research (Huinink/Hollstein, LIFE COURSE, this volume), comparative sociology, quantitative methodology (Barth/Blasius, QUANTITATIVE METHODS, this volume), or quantitative research on social inequality (Otte/Boehle/Kunißen, SOCIAL INEQUALITIES-EMPIRICAL FOCUS, this volume) and migration (Pries, MIGRATION, this volume). In many other areas, parts of the discussion predominantly take place in German with a certain "German twist" and with only certain parts of this discussion entering the international debate. For example, in technology studies the Germanspeaking research community has established a distinct sociological perspective on technological development compared to the rather interdisciplinary field of science and technology studies (STS) (Rammert, TECHNOLOGY AND INNOVATION, this volume).

Part of the reason why historically a great deal of scientific output was not published internationally is the sheer size and diversity of the German-speaking community. Today, more than 80 universities offer degrees in sociology in Germany, Austria, and Switzerland. The profession saw enormous growth, especially in the third

mantled and replaced by newly established institutes that were staffed primarily with West German scholars. 
quarter of the 20th century in the wake of booming Western economies, educational expansion, and cultural change. This development was particularly pronounced for West German sociology: After the founding of the Federal Republic of Germany in 1949, West German sociology restarted with just a handful of chairs in sociology, occupied, among others, by René König (Cologne), Helmut Schelsky (Hamburg/Münster), and Max Horkheimer (Frankfurt/Main), the latter with a chair also in philosophy. In 1960, there were about thirty sociological professorships, a number that increased tenfold by 1980 (Lepsius, 1979; Burkart and Wolf, 2002). Especially the generation of '68, who entered tenured professorships during this boom phase of sociology at an early age, did not need to publish in English, at least not for career promotion. Of course, there were several notable exceptions, such as Claus Offe and a little later Richard Münch and Ulrich Beck, to name but a few. But on the whole, this generation, which decisively shaped German sociology until their retirement around the turn of the millennium, was largely self-contained and felt no pressure to undertake the sometimes rocky endeavor of translating one's work into a foreign language and relating it to the wider international discourse. The situation has always been much different for smaller language communities, such as the Dutch academic community, who-owing to their smaller size-are more inclined to communicate in English for the purpose of professional recognition.

Yet, as mentioned above, there are still remarkable differences in the degree of internationalization between different fields of sociological research. This suggests that there are other reasons that come into play besides the overall size of the Germanspeaking sociological community. Certain parts of sociological analysis, such as the fine-grained advancement of philosophically grounded social theory or the nuanced interpretation of qualitative research material, require a level of language proficiency and linguistic skills that makes the endeavor of translation even more daunting. Furthermore, in some areas such as social theory and qualitative research, a substantial part of the research output still takes the form of monographs (at least in "teutonic academia"), which represents another hurdle given the strong competition for publishing opportunities in internationally renowned publishing houses. Additionally, the more theory-oriented and less pragmatic "teutonic" intellectual style might not always attract substantial interest in the Saxonian academic world (cf. Fiedler, 2012). Finally, there are some substantive debates in German-language sociology that are either unique to it or run contrary to trends in English-language sociology, thus making it difficult to connect them to international discussions, and perhaps also less attractive for German-speaking scholars to undertake the endeavor in the first place. This held true, for example, for large parts of the discussion on Ulrich Beck's individualization thesis (cf. Allmendinger and Ludwig-Mayerhofer, 2000) as well as for major parts of the quite advanced methodological discussion on interpretative methods (Hollstein/Kumkar, QUALITATIVE METHODS, this volume).

However, this situation is about to change. Since the mid-1990s, the German academic system has undergone distinct changes. Among others, "new public management" has brought about an increasing orientation towards performance indica- 
tors and a particularly strong focus on international publications. These changes are especially pertinent for the new generation of younger sociologists who are about to enter the academic job market. Now, at a time when the generational turnover in sociology has come to an end and most of the positions vacated by the retirement of the generation of ' 68 have been reappointed, the heightened competition is pressuring younger sociologists to focus much more on their international publication record than ever before, leading to a much higher internationalization in all areas of sociological research.

With the generational turnover now behind us, we think that this is a perfect time to take stock and ask what has been achieved so far and also to look ahead to the challenges sociology faces and the pressing open questions to which it can contribute. And as the motivation to publish in English is gaining momentum, this is also a perfect time to do so in English.

\section{The Articles in this Volume}

The thirty-four chapters assembled in this volume review the state of the art and the development in the respective fields of sociological research in German-speaking countries over the last 15 to 20 years. Since such a review is necessarily selective, we asked the authors to focus on important publications and major trends. What are the specific contributions of German-language sociology? What exactly is their relevance to the subject area in question, and how do they relate to the international discussion? Finally, each article points out challenges and perspectives for future research.

We consider this book to be a companion to German-language sociology, designed to be accessible and informative and to contribute to a better understanding of this diverse, lively, and innovative scientific community.

At this point, we must define more precisely what we mean when we speak of "sociology in the German-speaking world." This demarcation is not an easy task since many German-speaking authors today also publish in English. In this volume, we are concerned with the sociological discussions in Germany, Austria, and the Germanspeaking parts of Switzerland and the work of German-speaking authors, respectively. This does not only include German-language publications. To the contrary, we deliberately sought to include English publications in the bibliographies, if available, to enable readers not proficient in German to follow up on these discussions if they choose to do so.

The contributions in this volume span the full range of sociological research topics, from culture to work and labor, from social inequality to transnationalization and the Global South, from the sociology of the body and space to the environment, from trends in sociological theory to innovative research methods. To do justice to the breadth of the work on sociological theory and methodology and its significance in German-language sociology, we have included three articles on sociological theory (the chapters on SOCIAL THEORY, MICROSOCIOLOGY, and SOCIETY) and three arti- 
cles concerned with methods of empirical research (the chapters on QUANTITATIVE METHODS, QUALITATIVE METHODS, and MIXED-METHODS AND MULTIMETHOD RESEARCH).

We have deliberately chosen to arrange the articles in the alphabetical order of the contributions. This underlines the handbook nature of this volume and avoids the otherwise unavoidable hierarchization and prioritization of the subject areas, which is ultimately always arbitrary and unsatisfactory.

Some additional features have been added to support the accessibility, functionality, and usefulness of this companion. Keywords at the end of this volume should help the reader to find topics that are covered in several articles, such as digitalization (covered, e.g., in the chapters on MEDIA AND COMMUNICATION, TECHNOLOGY AND INNOVATION, and WORK AND LABOUR), knowledge (see, e.g., CULTURE, QUALITATIVE METHODS), or social change (MIGRATION, SOCIETY, LIFE COURSE). Cross-references point to other relevant articles.

Finally, we want to thank the people who have made significant contributions to this landmark undertaking. First and foremost, we would like to thank Stefan Giesen from the De Gruyter publishing house, who has accompanied the endeavor of publishing this special issue of SOZIOLOGISCHE REVUE with great enthusiasm and much support from the very beginning. Moreover, we would particularly like to acknowledge the help of the people from SocioTrans - Social Science Translation and Editing. With great diligence, Stephan Elkins and his team-Eric J. Iannelli, David Haney, John Koster, Karen Margolis, Cathleen Porter, and Andrea Tönjes-translated a number of the articles and copy-edited the entire volume. Siba Fitzau from the SOZIOLOGISCHE REVUE editorial team proofread the manuscripts with reliable accuracy and great commitment. We also want to thank Jessika Dirks and Florian König for their help with the index. Finally, we would like to express our gratitude to the University of Bremen, which made it possible to publish this volume in its entirety as open access. We hope this volume finds a wide distribution and a sympathetic readership.

Betina Hollstein, Rainer Greshoff, Uwe Schimank, and Anja Weiß

\section{References}

Adorno, T. W. Der Positivismusstreit in der deutschen Soziologie; Luchterhand: Darmstadt/Neuwied, 1969.

Allmendinger, J.; Ludwig-Mayerhofer, W. Sozialstruktur: Auf der Suche nach der verlorengegangenen Ungleichheit. In Soziologie 2000. Kritische Bestandsaufnahmen zu einer Soziologie für das 21. Jahrhundert, Special Issue 5 Soziologische Revue; Münch, R.; Jauß, C.; Stark, C., Eds.; Oldenbourg: Munich, 2000; pp 264-278.

Bolte, K. M.; Neidhardt, F., Eds. Soziologie als Beruf. Erinnerungen westdeutscher Hochschulprofessoren der Nachkriegsgeneration; Nomos: Baden-Baden, 1998. 
Bude, H.; Neidhardt, F. Die Professionalisierung der deutschen Nachkriegssoziologie. In Soziologie als Beruf. Erinnerungen westdeutscher Hochschulprofessoren der Nachkriegsgeneration; Bolte, K. M.; Neidhardt, F., Eds.; Nomos: Baden-Baden, 1998; pp 405-419.

Burkart, G.; Wolf, J., Eds. Lebenszeiten. Erkundungen zur Soziologie der Generationen; Leske + Budrich: Opladen, 2002.

Fiedler, S. Zur Kulturspezifik der Wissenschaftskommunikation. Interlinguistische Informationen, Beiheft 19: Fachkommunikation - interlinguistische Aspekte 2012, 39-50.

Fleck, C., Ed. Wege der Soziologie nach 1945. Biographische Notizen; Leske + Budrich: Opladen, 1996.

Galtung, J. Structure, Culture and Intellectual Style: An Essay Comparing Saxonic, Teutonic, Gallic and Nipponic Approaches. Social Science Information 1981, 20, 817-856.

Gouldner, A. W. Romanticism and Classicism: Deep Structures in Social Science. Diogenes 1973, 21, 88-107.

Hondrich, K.-O.; Matthes, J., Eds. Theorienvergleich in den Sozialwissenschaften; Luchterhand: Darmstadt/Neuwied, 1978.

Kneer, G.; Moebius, S., Eds. Soziologische Kontroversen; Suhrkamp: Frankfurt a.M., 2010.

Lepsius, M. R. Die Entwicklung der Soziologie nach dem zweiten Weltkrieg. 1945 bis 1967. In Deutsche Soziologie seit 1945. Entwicklungsrichtungen und Praxisbezug. Sonderheft $21 \mathrm{der}$ Kölner Zeitschrift für Soziologie und Sozialpsychologie; Lüschen, G., Ed.; Westdeutscher Verlag: Opladen, 1979; pp 25-71.

Lepsius, M. R. Das Erbe des Nationalsozialismus und die politische Kultur der Nachfolgestaaten des "Großdeutschen Reiches". In Kultur und Gesellschaft. Verhandlungen des 24. Deutschen Soziologentags, des 11. Österreichischen Soziologentags und des 8. Kongresses der Schweizerischen Gesellschaft für Soziologie in Zürich 1988; Haller, M.; Hoffmann-Nowotny, H.-J.; Zapf, W., Eds.; Campus: Frankfurt a.M./New York, 1989; pp 247-264.

Meyer, H. Social Research in the GDR. In Sociology in Germany. Developments - Institutionalization - Theoretical Disputes. Special Issue 3 Soziologie. Journal of the Deutsche Gesellschaft für Soziologie; Schäfers, B., Ed.; Leske + Budrich: Opladen, 1994; pp 33-52.

Schäfers, B., Ed. Sociology in Germany. Developments - Institutionalization - Theoretical Disputes. Special Issue 3 Soziologie. Journal of the Deutsche Gesellschaft für Soziologie; Leske + Budrich: Opladen, 1994.

Teckenberg, W. Transformation: Zehn Jahre Transformationsforschung. In Soziologie 2000. Kritische Bestandsaufnahmen zu einer Soziologie für das 21. Jahrhundert, Special Issue 5 Soziologische Revue; Münch, R.; Jauß, C.; Stark, C., Eds.; Oldenbourg: Munich, 2000; pp 303-313.

Wolle, S. Die versäumte Revolte: Die DDR und das Jahr 1968. Aus Politik und Zeitgeschichte 2001, B 22/23, 37-46. 